\title{
Response of tuberose to different levels of nitrogen, phosphorus and potassium fertilizers
}

\author{
Haider Mukhtar ${ }^{1}$, Fazli Wahid ${ }^{1}$, Fahad Noor $^{1 *}$, Muhammad Usman \\ Khan $^{1}$, Imran Qazi ${ }^{1}$, Huma Mumtaz Qureshi ${ }^{2}$, Muhammad Fasihuddin \\ Malik $^{1}$, Shahid Zaman ${ }^{1}$, Zeeshan Ahmad ${ }^{1}$ and Fatima Bibi ${ }^{1}$ \\ 1. Department of Horticulture, Faculty of Crop Production Sciences, The University of Agriculture Peshawar, KP, \\ 25130, Pakistan \\ 2. Department of Horticulture, University of Haripur, Haripur, KP, 22620, Pakistan \\ *Corresponding author's email: fahadnoor795@gmail.com, fahad.noor@aup.edu.pk \\ Citation \\ Haider Mukhtar, Fazli Wahid, Fahad Noor, Muhammad Usman Khan, Imran Qazi, Huma Mumtaz Qureshi, \\ Muhammad Fasihuddin Malik, Shahid Zaman, Zeeshan Ahmad and Fatima Bibi. Response of tuberose to \\ different levels of nitrogen, phosphorus and potassium fertilizer. Pure and Applied Biology. Vol. 11, Issue 3, \\ pp773-777. http://dx.doi.org/10.19045/bspab.2022.110078
}

\begin{tabular}{llll}
\hline \hline Received: 01/09/2021 & Revised: 13/11/2021 & Accepted: 18/11/2021 & Online First: 19/11/2021 \\
\hline
\end{tabular}

\section{Abstract}

Fertilizers are food for plants and they replace the nutrients that crops remove from the soil. Without the addition of fertilizers, crop yields and agricultural productivity would be significantly reduced. Keeping in view the importance of fertilizers, an experiment "Response of tuberose to different levels of nitrogen, phosphorus and potassium fertilizer" was conducted at Agricultural research institute Tarnab, Peshawar during summer 2018. The experiment was laid out in randomized complete block design with one factor with three replications (NPK control, $5 \mathrm{~g} \mathrm{~m}^{-2}, 10 \mathrm{~g} \mathrm{~m}^{-2}$, and $15 \mathrm{~g} \mathrm{~m}^{-2}$ ). The data were recorded on days to flowering, days to sprouting, spike length $(\mathrm{cm})$, number of leaves per spike, number of flowers per spike. All the parameters were non-significantly affected by nitrogen, phosphorus, and potash. Although the overall result was non-significant but still the maximum number of flowers per spike (22.667) at $15 \mathrm{~g} / \mathrm{m}^{2}$, maximum spike length $\left(3.6667 \mathrm{ft}\right.$.) at $15 \mathrm{~g} / \mathrm{m}^{2}$, and early flowering (88.667 days) was observed in $10 \mathrm{~g} / \mathrm{m}^{2}$. On the other hand, the maximum early sprouting was recorded maximum (85.667) at $10 \mathrm{~g} / \mathrm{m}^{2}$ and followed by $15 \mathrm{~g} / \mathrm{m}^{2}$, the number of leaves per spike show that maximum number of leaves per spike (8.0) were recorded at control and maximum length of flowers per spike (12.677) was recorded at control followed by level 15 (21.333), while the late emergence (98.333) observed in $10 \mathrm{~g} / \mathrm{m}^{2}$, minimum number of flowers (20.000) were recorded at control and minimum length of flowers (8.8333) were recorded at $5 \mathrm{~g} / \mathrm{m}^{2}$ another parameters the minimum number of leaves per spike $(5.0000)$ were recorded at $15 \mathrm{~g} / \mathrm{m}^{2}$, minimum spike length $\left(2.7233 \mathrm{ft}\right.$ ) value of mean was recorded at $10 \mathrm{~g} / \mathrm{m}^{2}$ and the minimum day to sprouting (22.333) mean value was recorded at control. All the results are recorded maximum as well as minimum at different level of NPK in this experiment.

Keywords: Tuberose; Nitrogen; Florets; Mineral nutrition

Introduction

Tuberose in a dazzling bulbous, perennial and day neutral plant. The Botanical name of tuberose is Polianthes tuberosa $\mathrm{L}$. belonging to family Asparagaceae. Its origin in Mexico and during the $16^{\text {th }}$ century is spread to deferent parts of the world. Tuberose consists of almost twelve 
species. Tuberose is commercially cultivated throughout the world and have a special position among ornamental flowers for its fascinating and long-lasting qualities. The popularity of tuberose is increasing day by day due to its adorable cut flowers. It occupies a very selective and special position to flow lovers as attractiveness, prettiness and enjoyable fragrance. Traditionally tuberose have enormous economic potential as cut flowers and in the field of the essential oil industry [1]. Tuberose flowers can be kept for a considerably prolonged period and remain fresh when cut and thus it has occupied a prominent place in flowers market. Due to its prolonged vase life, it is used for cutting flowers and is ideally cultivated in subtropical regions [2].

Nitrogen has an important role in the production of tuberose. Nitrogen influences certain attributes of tuberose plants, such as plant height, leaves quantity, number of spike, yield and flowering [3-5]. Cirrito [5] observed that nitrogen and potassium can together enhance the growth and development of tuberose. Nitrogen fertilizer is one of the most important factors in canopy formation and its deficiency leads to a decease in photosynthesis [6]. Nitrogen and phosphorus are necessary elements for growth [7]. Gangwar and Singh [8] mentioned N: P: K at 100: 150:150 kg ha ${ }^{-1}$ led to maximum growth and yield of the flowers. Nitrogen has a significant effect on tuberose bulb production. It has a good effect on increasing length of spike. Phosphors involve in many enzymatic reactions such as phosphorylation, energy transfer and some biochemical process [9]. Phosphorus is best for the growth, flowering and bulbs production of tuberose and due to its deficiency, the flowering and production. Potassium on the other hand also plays vital role in venous plant processes such as physiology and biochemistry, which are important for growth, quality, yield and stress resistance of the plant [10]. Moreover, potassium has an essential role in regulation of stomata involved in photosynthesis and transpiration, photophosphorylation, translocation of photosynthetic to the sink tissue, activation of enzymes, maintenance of turgor and tolerance to stress $[11,12]$.

The present study was conducted to determine optimum dose of nitrogen, phosphorus and potassium on growth, production and flowering of tuberose.

\section{Materials and Methods}

The experiment "Response of tuberose on different level of nitrogen, phosphorus and potassium fertilizers" was conducted at Floriculture Section, Agriculture Research Institute Tarnab, Peshawar (ARI Tarnab) during summer 2018. The experiment was laid out in Randomized Complete Block Design with split plot arrangement and there were four treatments and replicated three times.

\section{Factors}

Single factor (NPK)

To $=$ Control

$\mathrm{T} 1=5 \mathrm{~g} \mathrm{~m}^{-2}$

$\mathrm{T} 2=10 \mathrm{~g} \mathrm{~m}^{-2}$

$\mathrm{T} 3=15 \mathrm{~g} \mathrm{~m}^{-2}$

\section{PARAMETERS}

The following parameters were studied during the research project.

\section{Days to sprouting}

The number of days the date of sowing to date of sprouting was counted for each treatment in each replication and average was calculated.

\section{Days to flowering}

Number of days from the date of sowing to date of emergence was counted for each treatment in each replication and average was calculated.

\section{Spike length (cm)}

From each treatment in each replication five spikes were randomly selected, and their length was measured through measuring tape from soil surface to the tip of the plant and then average was calculated.

\section{Number of leaves per spike}

Leaves of five randomly selected spikes from each treatment in each replication 
were counted and then average was calculated.

\section{Number of flowers per spike}

From each treatment in each replication five spikes were randomly selected, flowers were counted, and average was calculated.

\section{Flower length per spike (ft.)}

From each treatment in each replication five spikes were randomly selected, and their flower length was measured through measuring tape first flower to last top flower and then average was calculated.

\section{Results and Discussion Days to sprouting}

Table 1 shows that days to sprouting were non-significantly affected by different levels of nitrogen phosphorus and potash. Regarding the mean value of days to sprouting was recorded maximum (85.667) at $10 \mathrm{~g} / \mathrm{m}^{2}$ and followed by $15 \mathrm{~g} / \mathrm{m}^{2}$ and $5 \mathrm{~g} / \mathrm{m}^{2}$ of NPK, while the minimum mean value was recorded at control however the mean of each level was different from one another. The same result was done by [13], according to her experiment days to sprouting is not significant affected by different levels of nitrogen phosphorus and potash.

\section{Days to flowering}

Mean data publicized that days to flowering were non-significantly affected by different levels of nitrogen phosphorus and potash. The mean value for days to flowering showed that early flowering (88.667 days) was observed in $10 \mathrm{~g} / \mathrm{m}^{2}$ and followed by control and $5 \mathrm{~g} / \mathrm{m}^{2}$ of NPK while late flowering (98.333 days) was observed at 15 $\mathrm{g} / \mathrm{m}^{2}$. However, the mean of each level was different from one another. The result agrees with [14] who reported nonsignificant effect by different levels of nitrogen, phosphorus and potash.

\section{Spike length (FT)}

Data analysis proved that spike length (ft.) were non-significantly affected by different levels of nitrogen phosphorus and potash. The mean values for spike length show that maximum spike length (3.6667 ft.) were recorded at $15 \mathrm{~g} / \mathrm{m}^{2}$ of NPK and followed by control and $5 \mathrm{~g} / \mathrm{m}^{2}$ of NPK, while the minimum value of mean was recorded at 10 $\mathrm{g} / \mathrm{m}^{2}$. It is the conformation of result obtained by Kabir et al. [15] who reported that spike length is not affected by different levels of nitrogen, phosphorus and potash.

\section{Number of leaves per spike}

Number of leaves per spike were nonsignificantly affected by different levels of nitrogen phosphorus and potash. In case of NPK, the mean values for number of leaves per spike show that maximum number of leaves per spike (8.0) were recorded at control and followed by $5 \mathrm{~g} / \mathrm{m}^{2}$ and $10 \mathrm{~g} / \mathrm{m}^{2}$ and the minimum were recorded at $15 \mathrm{~g} / \mathrm{m}^{2}$. The same result was obtained by Khaliji et al. [16], who were reported that vegetative attribute of tuberose is not significantly affected by different levels of nitrogen, phosphorus and potash.

\section{Number of flowers per spike}

Data regarding mean number of flowers per spike shown in Table- 1 . Number of flowers per spike were insignificantly affected by different levels of nitrogen phosphorus and potash LSD test shows that maximum number of flowers per spike (22.667) was recorded at level $15 \mathrm{~g} / \mathrm{m}^{2}$ followed by level $10 \mathrm{~g} / \mathrm{m}^{2}$ (21.333) while lowest mean was recorded at control however all the means were non-significant different from one another. The result show similarity with Larson [17] who reported non-significant effect of potash on number of flowers per spike.

\section{Length of flower $(\mathrm{cm})$}

Data regarding mean length of flowers per spike shown in (Table 1). It is clear from the data that length of flowers per spike were non-significantly affected by different levels of nitrogen phosphorus and potash. LSD test shows that the maximum length of flowers per spike (12.677) was recorded at control followed by level $15 \mathrm{~g} / \mathrm{m}^{2}$ (21.333) while lowest mean was recorded at level 5 however all the means were non-significant different from one another. 
Table 1. Responses of tube rose at different levels of nitrogen phosphorus and potassium fertilizer

\begin{tabular}{|c|c|c|c|c|c|c|}
\hline Treatment & $\begin{array}{c}\text { Days to } \\
\text { sprouting }\end{array}$ & $\begin{array}{c}\text { Days to } \\
\text { flowering }\end{array}$ & $\begin{array}{c}\text { Spike } \\
\text { length } \\
\text { (ft.) }\end{array}$ & $\begin{array}{c}\text { Number of } \\
\text { leaves } \\
\text { spike }\end{array}$ & $\begin{array}{c}\text { Number } \\
\text { of } \\
\text { flowers } \\
\text { spike }\end{array}$ & $\begin{array}{c}\text { Length } \\
\text { of } \\
\text { flower } \\
\text { (cm) }\end{array}$ \\
\hline \multicolumn{7}{|c|}{ NPK $\left(\mathbf{g}^{-m^{-2}}\right)$} \\
\hline $\mathbf{0}$ (Control) & $22.33 \mathrm{~A}$ & $91.00 \mathrm{~A}$ & $2.83 \mathrm{~A}$ & $8.00 \mathrm{~A}$ & $20.00 \mathrm{~A}$ & $12.67 \mathrm{~A}$ \\
\hline $\mathbf{5}$ & $24.66 \mathrm{~A}$ & $90.66 \mathrm{~A}$ & $2.93 \mathrm{~A}$ & $7.00 \mathrm{AB}$ & $20,00 \mathrm{~A}$ & $8.83 \mathrm{~A}$ \\
\hline $\mathbf{1 0}$ & $26.42 \mathrm{~A}$ & $88.66 \mathrm{~A}$ & $2.72 \mathrm{~A}$ & $5.66 \mathrm{BC}$ & $21.33 \mathrm{~A}$ & $11.00 \mathrm{~A}$ \\
\hline $\mathbf{1 5}$ & $27.00 \mathrm{~A}$ & $92.33 \mathrm{~A}$ & $3.66 \mathrm{~A}$ & $5.00 \mathrm{C}$ & $22.66 \mathrm{~A}$ & $10.33 \mathrm{~A}$ \\
\hline
\end{tabular}

Mean values followed by different letter differ from each other at $5 \%$ level of significance

\section{Conclusion}

From the experiment it is concluded that the overall effect of different levels of nitrogen, phosphorus and potash is found nonsignificant on the all parameters during the study. It may be due to the following factors i.e. Bulb size, soil fertility status, weeding competition, early harvesting and nutrient imbalance etc.

\section{Authors' contributions}

Conceived and designed the experiments: H Mukhtar \& F Wahid, Performed the experiments: H Mukhtar \& F Noor, Analyzed the data: HM Qureshi, S Zaman \& Z Ahmad, Contributed reagents/ materials/ analysis tools: I Qazi, MU Khan $\&$ MF Malik, Wrote the paper: F Noor \& Fa Bibi.

\section{References}

1. Avinash, Rathore \& Sing (2013). Effect of graded levels of nitrogen on production of flower, oil and bulb of tuberose (Polianthes tuberosa L). Hortflora Res Spec 2(1): 60-63.

2. Amin, Faridujjaman \& Jamal U (2012). Phosphorus levels on growth and flowering of tuberose (Polianthes tuberosa L.). Bangl Res Publ J 4(7): 324-330.

3. Boshra \& Sayed (2012). Effect of potassium fertilization sources, bulb size and their interactions on growth and flowering of tuberose (Polianthes tuberosa L). Res J Agric and Biol Sci 2(8): 250-255.

4. Chandy KT (1994). Tuberose Booklet No 405. Flower Gardening: F G S-35.
5. Cirrito M (1975). The effects of manuring and bulbil circumference on the enlargement of bulbs of tuberose. Annali dell Institute to sperimentale per la Floriculture. 6(1): 27-43.

6. Cakmak I (2005). The role of potassium in alleviating detrimental effect of biotic stresses in plants. J Plant Nutr Soil Sci 168: 521-530.

7. Das TK, Mitra AK \& Shanker SC (1988). Economics of tuberose cultivation in Nadia district (West Bangal). Econ Affiars Calcutta 33(2): 103-106.

8. Gangwar \& Singh JP (2012). Effect of nitrogen and phosphorus with nitrogen sources on vegetative attributes of tuberose. Hort Flora Res Spec 2(1): 4044.

9. Ghosh \& Siracole (2010). Effect of different sources and levels of potassium on growth, flowering and yield of African marigold (Tageteseracta Linn.) Deptt of floriculture and landscaping, Bidhan Chandra Krishi Viswavidyalaya, Nadia, West Bangal, India Mohanpur-741252.

10. Hung KL, Miyajima I, Okubo H, Shen TM \& Huang TS (2001) Breeding of colored tuberose Polianthes tuberosa L and cultural experiments in Taiwan. Acta Hort 570: 3657-371

11. Hessayun DG (1995). The Bulb Expert. Transworld Publishers Ltd. London. First Edition 128.

12. Hussain S (1999). Effect of bulb size and depth of planting on growth and 
flowering of tuberose (Polianthes tuberosa L). cv. songle. Deptt. Hort, Univ Agriculture Faisalabad, Pakistan.

13. Hossain MDK (2008). Influence of bulb size and phosphorus on growth and flowering of tuberose cv. songle. M.Sc. thesis submitted to the Deptt. Of Hort \& post-harvest Tech, sher-e-Bangla AgricUni, Dhaka Reg. No. 00876.

14. Javid QA, Abbasi NA, Hafiz IA \& Mughal AI (2005) Performence of Zinnia (Zinnia elegans) "Dahlia flowered" crimson shad by application of NPK fertilizer. Inter $J$ of Agric \& Biol 7(3): 471-473.
15. Kabir AMH, Imran MMA, Mondal \& Chowdhury S (2011) Response of Tuberose to integrated Nutrients Management. J Environ Sci and Natur Res 4(2): 55-59.

16. Khalij MA, Edrisi B \& Amiri M (2012). Effect of nitrogen and plant spacing on nutrients uptake, yield and growth of tuberose (Polianthes tuberosa L). J Ornam \& Horti. Pl 2(1): 45-54.

17. Larson EL (1980) Introduction to Floriculture. 607. Academic press London. 